\title{
The futures of entertainment dependent cities in a post-COVID world
}

\author{
Louis-Etienne Dubois and Frederic Dimanche
}

\author{
Louis-Etienne Dubois is \\ based at the School of \\ Creative Industries, \\ Ryerson University, \\ Toronto, Canada. \\ Frederic Dimanche is \\ based at the Ted Rogers \\ School of Hospitality and \\ Tourism Management, \\ Ryerson University, \\ Toronto, Canada.
}

\begin{abstract}
Purpose - The purpose of this study is to examine post-crisis (COVID) futures for major city destinations that are dependent on live entertainment and tourism. Destinations that live from entertainment and tourism must consider the implications of the pandemic and plan strategies for their future.

Design/methodology/approach - Based on the Manoa School of Future Studies, four scenarios were identified following a review of current literature. These scenarios (alternate futures) were then discussed in two videoconference focus groups by tourism marketing and entertainment expert professionals from five major North American entertainment cities.

Findings - Typical tourism responses to crises and disasters do not appear to apply to the current pandemic and entertainment-dependent destinations (EDDs) are not prepared to thrive in any of the potential outcomes.

Originality/value - This is the first study addressing the future of EDDs in a COVID world. This study cannot predict the future, but this study can make some forecasts. It is important for scholars and professionals to work together toward identifying what can be.
\end{abstract}

Keywords Disaster management, Destination marketing, COVID-19 pandemic, Entertainment tourism Paper type Research paper

\section{Introduction}

Despite a few suspected cases in late 2019, the COVID-19 outbreak gained momentum in the early months of 2020. As cases rapidly began to spike, the World Health Organization declared a state of global pandemic in March of that year (WHO, 2020). A higher death rate than other known sources of flu, remarkably easy dissemination, unknown long-term effects and lack of available treatment all contributed to drastic government actions to curb the spread of the virus (Imbert, 2020).

While COVID-19-related closures were a rational move to contain the pandemic, prevailing standards in industries such as tourism and live entertainment are antithetical to social distancing. Strict restrictions have seriously impaired these industries' business models and operations, leading many of them to the brink of bankruptcy (Zoltner et al., 2020). The magnitude of these measures' impact is especially salient to mono-industry destinations that rely heavily on the entertainment sector, many of whom just recovered from the 2008 economic crisis. As crowds become danger zones, the toll on cities such as Las Vegas, Macau and New Orleans but also on a smaller scale, vicinities such as Broadway (NYC) and London's West End has been simply brutal (Kuznia, 2020).

Consistent with entertainment-tourism (Luo and Lam, 2017) and arts-related tourism (Hughes, 2013) research, we call "entertainment-dependent destinations" (EDDs) these locations whose vitality depends heavily on this single industry (Hughes, 2013) and posit that the combined impact of travel and mass-gathering restrictions because of COVID-19 amount to that of a disaster. As such, this article draws from the disaster management 
literature and examines possible post-pandemic strategies for EDDs. Industry experts' responses to four alternate images of the future (Dator, 1998, 2019) often depart from existing disaster management strategies that appear limited in this particular instance. More importantly, it suggests that the lack of planning combined with the magnitude and nature of the damage incurred leaves EDDs ill-prepared for any of these futures. Theoretical implications and potential disaster management strategies for EDDs are also discussed.

\section{Context}

Since the beginning of the COVID-19 pandemic, bans on mass gatherings have most directly impacted live entertainment and performing arts (Canada Council for the Arts, 2020; Kuznia, 2020). The compounded effect of closed venues and borders, as well as a public aversion for crowds, have resulted in anemic ticket sales, mass layoffs and permanent damage. Travel restrictions and public health guidelines have led to a slew of cancellations as performers were denied entry or forced to quarantine upon return. As a result, many live performance organizations chose to go dormant or bankrupt, thereby creating a ripple effect in the broader entertainment ecosystem (Hissong, 2020).

The fear is now that the pandemic's broader socio-economic impacts are likely to prevent "business as usual" when venues and borders finally re-open. Between employees have moved on to other careers and a global economic depression with record unemployment in many countries (Bremmer, 2020), recovery is expected to be a slow, sluggish and non-linear process. In addition to heightened employment insecurity, lingering concerns may also be detrimental for future ticket-sales. Even with proper plans and measures, audiences ever returning is far from granted (Ricciardelli, 2020).

Concerts, musicals and magic shows and have long been core products in select entertainment destinations (Luo and Lam, 2017), who must now concurrently cope with a seriously hampered tourism industry. Indeed, According, an estimated $90 \%$ of the world's population has been affected by travel restrictions, including border closures, strict quarantine measures and outright bans (Gössling et al., 2020). Limited flights also mean empty hotels and restaurants at destinations. For the first half of 2020 alone, this translated into a US\$440bn loss globally (UNWTO, 2020).

Thus, in addition to the entertainment sector's woes, cities such as Las Vegas have effectively been hit twice over by the crisis. Considering that $48 \%$ of visitors normally fly (GLS Research, 2018), COVID-19's intertwined impacts have been unparalleled. Indeed, the unprecedented statewide closure of all "non-essential" businesses, including casinos, hotels and attractions is said to have put 320,000 jobs at risk and could push Nevada's unemployment rate above 30\% (Sayre, 2020). Thousands of Las Vegas residents have already lost their jobs following the ban on mass gatherings, pushing local unemployment rate toward 20\% (Kirkpatrick and Lee, 2020). It is further estimated that each month the Nevada tourism industry is shut down, there are US\$4.7bn in economic losses (Komenda, 2020). Similarly, Broadway, whose spectators are predominantly tourists, is expected to lose billions (\$US), most of it being shouldered by nearby hotels, restaurants and shops (Whitten, 2020). Such figures are consistent with Macau's entertainment scene dire situation during the 2008 economic crisis, which at the time accounted for roughly $90 \%$ of the city's gross domestic product (Chan, 2011).

\section{Theoretical background}

Arguably, human-made crises, pandemics and natural disasters are common occurrences for the tourism industry and are to be expected. Regardless of the hazard's predictability, all destinations stand to be impacted and to face negative effects to their economy, infrastructure and population (Filimonau and De Coteau, 2020). As Faulkner (2001) explains, such situations are generally sudden and often induced by external, 
uncontrollable forces. However, between the Spanish Flu, the severe acute respiratory syndrome (SARS) and the H1N1 influenza, health scares are nothing new and have become almost "normalized" in the tourism community (Hall et al., 2020). While pandemics remain difficult to predict, they might not always be considered as random and unavoidable either. In fact, a flu pandemic was seen as a "crisis waiting to happen" (Page et al., 2010). Thus, in addition to conducting risk assessments and establishing robust contingency ahead of time, destinations should be ready to roll out rapid-response plans, as well as short- and long-term recovery actions when disasters occur (Faulkner, 2001).

Given that the present study is future-oriented and that the COVID-19 pandemic has already morphed in a prolonged, "sustained" crisis (Parsons, 1996), research suggests that EDDs ought to focus on efforts to reduce and recover from the impact of the disaster, as well as on implementing measures to prevent future damages. This includes redeploying resources or generating new ones to address urgent needs and restore services, developing communication strategies and working alongside all parties to clean up, repair and reinvest (Faulkner and Vikulov, 2001; Ritchie, 2004).

Once routine has been re-established, destinations' attention generally shifts to attempting to attract tourists and regain market shares. For instance, following the Arab Spring uprisings, marketers worked on influencing or replacing the sources that they believe spread negative information about the destination, convincing prospective visitors that some perceptions were not true and constantly reassuring these visitors (Avraham, 2015). Similar strategies were deployed in Asia or in New Orleans to combat stereotypes, repair destination image and bring back visitors following crises (Avraham and Ketter, 2017; Gotham, 2017). In regard to destinations affected by the refugee crisis, perceived security tends to become a stronger predictor for travel while also decreasing the relative importance of a place's perceived openness (Zenker et al., 2019). Thus, restoring confidence and providing reassurance is a key post-crisis action (Page et al., 2006). This is typically best achieved through close coordination with local stakeholders who must pool resources to put out consistent and impactful communications (Filimonau and De Coteau, 2020).

Destinations impacted by the disaster may also consider targeting unaffected market segments, rolling out aggressive recovery promotions and engaging industry personnel in communication efforts (Campiranon and Scott, 2014). Backer and Ritchie (2017) also suggest targeting the "visiting friends and relatives" segment after a crisis, as well as focusing on domestic or nearby travelers, much like the Niagara hoteliers did after the SARS crisis (Jayawardena et al., 2008). However, such strategies come with limitations. For instance, while an influx of Asia and Oceania visitors and "word-of-mouth" from international travelers helped Las Vegas recover after the 2008 crisis (Lim and Won, 2020), the borders remained mostly open and the economy experienced a strong rebound.

A year into this pandemic, the situation is grim and the future remains unclear. Conflicting reports, tensions between sanitary, political or economic objectives, re-openings followed by shutdowns: when and how live entertainment and travel can resume, as well as the toll on destinations directly impacted by these industries is still very much unknown. For EDDs already coping with more immediate concerns, planning and rolling out recovery measures has become a very complex task.

\section{Methodology}

As the COVID-19 pandemic continues to unfold with no end in sight, exploring the disaster's impacts and potential recovery strategies using a long-time horizon appears fitting. This research draws from the Manoa School of Future Studies framework, which entails using four generic futures - grow, collapse, discipline, transform - each representing plausible, possible images of things to come (Dator, 1998, 2019). These alternate futures stem from a 
different set of assumptions regarding seven main driving forces, namely, technology, energy, economics, population, environment, culture and governance. As such, they are not just the work of fiction, but rather informed images.

Such scenarios have often been used by researchers (Page et al., 2010; Postma, 2015; Yeoman, 2012; Yeoman and McMahon-Beattie, 2005), as well as by business and government planners to envision outcomes during uncertain times. We began by conducting a month-long secondary data collection phase on the impact of COVID-19 on the entertainment industry and tourism. From that material, four narratives (see below) were created, each articulating plausible, yet different future outcomes.

We then identified and contacted industry experts or powerful stakeholders (Loi and Pearce, 2012), to take part in focus groups to be held in a video-conference mode. Having between six and eight participants is typically sufficient (Krueger and Casey, 2000) for focus groups, and purposive sampling is recommended for studies when experts are called to provide relevant information (Morgan, 1988). Because the discussions were to happen online, groups were limited to five participants. This situation is also common when dealing with a small population of experts who are difficult to reach and when it is necessary for the topic to be discussed in groups. In this case, "researchers can only convene a small group of between two and five participants" (Nyumba et al., 2018, p. 24). In total, 15 experts were invited to participate. All held leadership positions in either the live entertainment business or at destination marketing organizations in five of the major EDDs in North America, namely, Austin, Las Vegas, Nashville, New Orleans and Toronto. Three declined and another three could not make themselves available, resulting in a final sample of nine experts.

The two 90-min group interviews were conducted online with the experts (Table 1) who received the four scenarios to be discussed prior to their session and were tasked with highlighting disaster management implications and suggesting strategies for each of the futures. One of the researchers led the interviews while the other researcher and the research assistant captured the discussion. The questions probed for impacts and necessary adjustments, not on the likelihood of such outcomes.

\section{Future \#1: Show must go on}

In this scenario, the pandemic merely turned out to be a blip in the overall upward progress of entertainment, tourism and of humanity in general, much like after the 9/11 attacks or the SARS outbreak. Despite governments' varying degrees of success in flattening the spread curve, the development of a vaccine proved to be very effective in eradicating the virus and life mostly returned to normal in 2022. By then, administrations had already relaxed restriction measures, although it was not always advisable, as to not damage their economies further or hurt their re-election odds. EDDs continued to grow and thrive as they

\section{Table 1 List of group-discussion expert participants}

\begin{tabular}{lll} 
Respondent \# & Destination & Sector \\
\hline 1 & New Orleans & Tourism \\
2 & New Orleans & Entertainment \\
3 & Toronto & Tourism \\
4 & New Orleans & Tourism \\
5 & Nashville & Tourism \\
6 & Austin & Entertainment \\
7 & Las Vegas & Entertainment \\
8 & Las Vegas & Entertainment \\
9 & Toronto & Entertainment
\end{tabular}


did for the past decades, further cementing their brands as welcoming locations for tourists seeking unique experiences and world-class entertainment.

Future \#2: Lights-Out

In the future, the pandemic brought the end of entertainment as we knew it. The first COVID-19 outbreak was just the beginning; the virus fell into a pattern of mutation, waves and recurrence. Vaccines could not keep up with said mutations, and geopolitical tensions hindered worldwide distribution. Extended distress caused by the economic shock sent global outputs into a tailspin as production and distribution were disrupted, coupled with deep unemployment. Racism and xenophobia became rampant, much like throughout history when infectious diseases became linked with othering. Performing arts became the last of people's priorities. The prolonged pandemic and border closures dealt a lethal blow to EDDs that relied on both audiences and performers traveling.

Future \#3: Less is more

COVID-19 brought renewed attention on the other threats to earth's habitability, and to the limits of current business models. Sustainability became a priority and the environmental footprint of many sectors, including tourism, was lowered immensely. Activists demanded changes and, through widespread boycott, drove reluctant companies out of business. Along with physical distancing rules, the environment-first mentality made large events, casinos and convention centers antiquated. EDDs, with their perceived artificial nature and meaningless contributions to society, struggled to re-invent themselves. While other futures imply that individuals were unable to travel because of restrictions, this one suggests that staying put actually became a conscious and preferred decision.

\section{Future \#4: Bigger is better}

The pandemic proved to be a formidable incubator for technologies, creativity and social programs. Such innovations led to significant changes in how entertainment is produced and consumed, as well as to impressive growth and unprecedented demand. Entertainment organizations, and, in turn, EDDs, failed to anticipate not just a recovery, but an acceleration and an evolution in demand. New offerings emerged, catering to an increasingly demanding audience who had grown tired of at-home entertainment. The drop in energy prices further ignited the industry and made travel and touring cheaper. Productions became bigger and flashier, which, in turn, attracted more tourists to EDDs.

\section{Results}

Surprisingly, all of the respondents expressed a keen sense of familiarity with each of the very different futures, while also pointing to important distinctions that make the COVID-19 pandemic unique, and consequently much more complicated to cope with using known post-crisis strategies.

\section{Future \#1}

Despite the magnitude and length of this disaster, respondents point to a feeling of déjà-vu. For instance, those from New Orleans vividly remember the destination's remarkable resilience following hurricane Katrina, much like those in Toronto are quick to point out to the SARS episode as evidence that tourism and entertainment can indeed bounce back rapidly. It remains, however, that the COVID-19 pandemic is unique on many levels. As one respondent explains:

[...] what makes this time different is that with Katrina we were isolated. People from outside came to help us. Now everyone is affected, and so we can't depend on other people to help with recovery $(\mathrm{R} 1)$.

Thus, even if a sharp economic recovery came to be, respondents note that damages may hinder the reboot for EDDs. Specifically, venues being rendered inadequate, industry 
workers have moved on to careers in other sectors or lingering audience fears may all lead to a sluggish, if not failed restart.

Thus, respondents suggest that destinations will need to orchestrate public relations efforts as part of their strategy:

In the case of Katrina, workers didn't even have a place to live anymore. We had to show the world the downtown area wasn't as damaged as the news said it was. That is what we're all going to do again. We have to show people what an attraction, restaurant, experience will be like so that people feel comfortable coming back (R2).

Others point that even such a proven strategy has limitations because those targeted by these communications are equally devastated this time around. The ability to resume operations is also believed to be contingent on the size and structure of the local entertainment ecosystems. For instance, while some in the hospitality industry have used this down time to conduct facility upgrades so that they could be ready when demand resumes, those in smaller markets may not have had the time or the resources to pull it together:

Austin was built organically, and in a semi-recent future. Because most businesses are small, on the margins, you'll find this is a lot more fragile. It would take a lot more finesse to turn that switch back on (R6).

In this scenario, EDDs also expect to face stiff competition as concerts and travel are set to resume all around the same time. This implies that destinations will likely have to spend more on marketing and sanitation measures to reassure prospective guests, as well as to capture their attention. Overcoming people's hesitation and persistent skepticism will come at a cost, which, again, not every destination may be equally able to afford. Respecting behavioral changes and audience sensitivities will also include rethinking spaces, reducing capacity for venues and hotels, sanitization protocols and replacing traditional touchpoints. Respondents believe that such measures are bound to remain in place for a while and ultimately be used as a marketing tool by many destinations. Indeed, communication strategies about being "healthier than they are" may well become the next tourism arms race for EDDs equally desperate to recoup lost revenues and regain their market shares.

Future \#2

While respondents admittedly struggled to devise potential recovery strategies for EDDs to thrive in such a devastated future, imagining it coming to be was not as hard. In fact, according to a respondent from the Las Vegas entertainment sector, collapse is what they are dealing with now. According to another one: we were already dealing with those problems before the pandemic too: affordability, artists struggling, venues closing. Its an ongoing challenge to maintain this fragile ecosystem (R4). Unsustainable business models, lack of investments in capacity building, evolving competition; some respondents believed that the writing was already on the wall before the current pandemic.

In terms of disaster management strategies in a collapsed ecosystem, one respondent mentioned that the implementation of strict travel "corridors" or "sister cities" partnerships could help bolster economic activity between a few communities deemed safe. As such, in addition to favoring domestic, mainly drive markets, EDDs could establish safe corridors and promote to select markets. In any case, communication efforts and marketing would likely target very different audiences. Gone would be the all-important convention business because of travel and entertainment restrictions, replaced instead by some risk-takers and bargain-hunters looking for cheap thrills and hotel rates.

On the bright side, big convention hotels often located in desirable areas could be repurposed, likely into apartment complexes, hence solving housing problems in many of those popular destinations. Further, because of enviable geographic locations, some EDDs 
could expect to maintain some level of activity: in Nashville, we have the distinct geographic advantage of being able to market to a 360 radius. We also have significant metropolitan areas within 2 to $4 \mathrm{~h}$ drive (R5). Yet, even those destinations could do little to counter the fear of others and an overall lack of appetite for gatherings. It is also believed that urban agglomerations would resist longer because of the size of their local market, whereas secluded areas would be hit the hardest by prolonged travel restrictions.

Interestingly, respondents believe that not everyone would end up complying with strict restrictions and that some form of entertainment would remain, albeit in a more clandestine way. In fact, these kinds of "underground" performances are said to be already taking place, be it in house parties or other private settings. The same goes for travel, where EDDs have been seeing a lot of illegal workarounds. As one respondent explains:

[...] people know too well that if you drive from Florida, avoid highways, you can skip checkpoints and get to Louisiana. People will get around it one way or another. Saying you can't cross state lines is like saying you can only pee in this part of the pool. Sooner or later, it is bound to leak and infiltrate (R1).

With that being said, clandestine performances and a depressed economy are unlikely to generate disposable income or tax revenues. In fact, it would further play against "struggling artists" who depend on those hospitality jobs to survive. Given EDDs' reliance on hotel taxes and tourism revenues, services to the population would be greatly affected, raising further concerns on their real and perceived safety, desirability and image.

\section{Future \#3}

Most respondents agree that the seeds of a more disciplined world were planted long before the pandemic and were already beginning to change the face of tourism and entertainment. While COVID-19 has encouraged EDDs to be even more mindful and to envision a more restrained approach to growth, talks of a sustainable, environmentally-friendly future predate the crisis.

Implications for such a future are plentiful. For one, respondents believe that entertainment organizations and artists will inevitably have to streamline, if not completely strip down their productions and to go back to much simpler offerings. Shows that are more "raw", environmentally optimized routes, priority given to the local sourcing of equipment and talent; in a way, this is seen as a welcome departure from computerized voices, glitz and overly large productions that travel with two complete sets of rigs. More sustainable models, such as Branson, Missouri, where artists set up camp and perform outdoor for a few days, could even become the norm. From a financial standpoint, only by reducing these costs can entertainment companies survive with limited audiences. EDDs, however, with high fixed costs and overly large infrastructures to support would likely struggle.

EDDs such as New Orleans that have developed a reputation about local culture, as well as authentic and smaller productions, are more likely to thrive. Likewise, destinations such as Austin with plenty of outdoor venue options are also expected to have an easier time, pushing other EDDs to invest in this type of infrastructure. Yet, this model comes with important limitations. For instance, the weather may not allow for year-round activities, nor may the local population be large enough or interested enough to sustain a sector in which people chose to stay put by choice or because of deterring prices. As one respondent explains, we are not into the Beyoncé type of entertainment. Problem is, the people who are interested in authentic New Orleans music are people who visit the city, not people who live here (R1). The changing nature of work, and what it means for the all-important convention business, is also likely to further impact EDDs' recovery strategies. Specifically, with more people working from home or from anywhere, some respondents believe that entertainment producers are likely to turn to the countryside and other niche destinations. As one explains, local circus, theatre companies can make a short trek to rural or resort areas, with 2 
performers instead of 76 (R8). If this scenario occurs, most respondents admit that finding a new positioning for large EDDs will prove complicated, for convention business can hardly exist without live performance.

\section{Future \#4}

A scenario in which demand not only resumes, but explodes, is paradoxically both easy and challenging to imagine for the respondents. Easy, because some of them were already experiencing steep growth before COVID-19 and projecting themselves into a world with more demand and bigger productions feels quite familiar. Yet, challenging for most, as the current situation seems so dire that any talks of growth, let alone of exponential nature, seem frivolous. One strategy that generates consensus is to further develop infrastructure and capacity to meet such pent-up demand. As one respondent explains:

It would take a decade just to secure the workforce to handle this growth. It would also take 10 years for airlines to become stronger, develop routes and airports to be able to move such a volume of people (R5).

The stress on the hospitality sector would be significant, especially given that hotels have had to let go a significant number of workers and would not be able to resume operations at a normal level. The entertainment industry finds itself in a similar situation, in which many employees have moved from their previous employer after being laid off, effectively impacting their post-COVID capacity. Furthermore, because most productions and live performance artists need months to develop, rehearse and set up for opening nights, the fact that entertainment companies have been stalled for months precludes business growth for some time.

Likewise, respondents remain wary of potential overtourism, especially, as a lot of them were already nearing that critical stage prior to the pandemic and beginning to experience some of the associated tensions:

Too much of a good thing is possible. We were at that tipping point. We were wondering if the city could manage growth better. How can we spread it out so there's more people in other areas? It's a concern, a real issue globally (R6).

Among the possible ways to mitigate a growing influx of entertainment tourists, respondents mentioned working with authorities to regulate licenses for productions but also where and when they are allowed to roll into town. It also involves planning for additional police presence to avoid further exacerbating tensions with locals by trying to push tourists out of the entertainment quarters: after Vegas, let's encourage them to visit Bryce Canyon. We would need to grow outward. Not just the destination, but surrounding ones too (R8).

Finally, respondents expect large entertainment companies to call all the shots and to only target a few suitable destinations for their productions. In fact, this trend was also being felt before COVID, as per this respondent:

Live Nation and AEG (large entertainment companies) were buying everything and tipping bargaining power in their favor. I don't think that's all good, because small destinations can't compete unless they step up capacity and accommodate them. These companies have to stop, or they risk destroying smaller ecosystems (R7).

In the end, only destinations with suitable capacity or with an ability to scale up are expected to be able to work with these new entertainment giants.

\section{Discussion}

The recovery strategies put forth by the participants draw at times from the disaster management literature, yet also suggest new directions to account for both the magnitude and unique nature of the COVID-19 pandemic. There are very few examples, if any, of times 
like these where every destination gets impacted at the same time. Thus, unlike other more circumscribed disasters, EDDs cannot expect the same level of external assistance for immediate and long-term recovery. It is not only that tourists and performers cannot reach the destination because it has incurred damage but also that they are unlikely to be able or willing to leave in the first place. The results also point to both new opportunities by drawing attention to market segments prepared to go outside of rules and restrictions, as well as new challenges such as shifting power dynamics between stakeholders. Likewise, typical post-disaster outreach and promotional efforts were seldom imagined to be competing with every other tourism destination also returning to normalcy once the pandemic finally ends, nor to compensate for several months' worth of negative media coverage. In addition, that does not even factor other pre-existing issues or concurrent, convergent crises of social and political nature that most of these North American cities are dealing with. In short, COVID-19 has proven to be a perfect storm for EDDs, and the actions required to recover from it will need to be equally perfect.

Consistent with the literature, EDDs seem prepared to maintain some of the current measures and to actively communicate on them, including social distancing and sanitization, to project an image of safety and reassure prospective travelers. Likewise, many EDDs appear poised to begin by rolling out promotional campaigns and reboot strategies aimed at local markets, in line with "visiting friends and relatives" initiatives (Backer and Ritchie, 2017). However, the results show that geographic considerations can be at times an advantage, at times a disadvantage. EDDs that are centrally located within a densely populated radius are bound to have an easier time catering to the drive market, whereas those in coastal areas find themselves with a smaller pool of potential visitors. Geography also comes into play when contemplating outdoor venues as the EDDs' latitude is likely to determine the range of options and the seasonality of the entertainment offerings. In addition, it has been argued that local populations may not be as interested in local offerings. The idea of working with twin "safe" cities seemed very interesting and could lead to novel marketing strategies.

Capacity and infrastructure considerations also appear central to the respondents' strategies. The results show that even in an optimistic scenario, EDDs have experienced and continue to do so - damage and may not be able to resume operations at full capacity, be it because of personnel attrition or infrastructure being rendered inadequate for new safety requirements. Thus, in this particular instance, the "refurbishing infrastructure" effort (Faulkner, 2001) is related to both replenishing human resources and remodeling spaces, as opposed to actual construction or rebuilding. In some cases, it may even include having to deal with excess infrastructure, at times by using it to address pressing local needs. Instances of hotels being used as senior homes or as shelters for the homeless (Labbé, 2020) or as remote working spaces (Caillou, 2020) suggest that this capacity is already in the process of being relocated toward the local. While venues and hotels have been used in the past as temporary shelters in times of crisis - the New Orleans Superdome during and following hurricane Katrina being a vivid example - a more permanent shift may end up significantly reshaping EDDs.

It is also worth noting how the four futures touched to ongoing or growing concerns among EDDs, which are going to command attention regardless of the pandemic's outcome. Here again, the existing literature does not always account for destinations' pre-existing issues and how they are exacerbated or further manifested during disasters. For instance, there appears to be a general unpreparedness or lack of solutions to overtourism and gentrification that either pushes out or prices out locals from entertainment areas, to changes in audiences and tourists' sensitivities in terms of content and experiences or to shifting power dynamics in the entertainment industry. While the pandemic has furthered exposed these issues, the general consensus among respondents is that simply going back to "normal" is not nearly enough. Perhaps, as Faulkner (2001) argues, this latest 
disaster will act as a pivotal moment in the development of these EDDs. While it is still too early to say if any of the calls - for more inclusion, more sustainability, etc. - are going to be answered (Hall et al., 2020), certain types of EDDs seem like a better fit for specific outcomes. Specifically, smaller, more "authentic" EDDs appear better equipped to deal with "collapse" and "discipline" futures, while larger, more commercial EDDs should hope for "continued growth" and "transformation" futures.

\section{Implications and conclusion}

This study provides EDDs with recovery strategies through an exploration of alternate futures. It also shows the limits of existing models that unfold along discrete stages (Faulkner, 2001; Roberts, 1994) and generally fails to account for this kind of iterative and all-compassing disasters. From a theoretical standpoint, this calls for the development of disaster management frameworks that are more fluid and compatible with sustained, multi-location and multi-episode disasters.

What happens next remains unpredictable. Butler (2009, p. 351) once suggested that it "would be unwise to imagine that tourism is going to decline sharply or even significantly in the short-term future" and that it would take "a combination of events or combined government and global action to halt the continued growth of tourism." Yet, this is exactly what happened: As a result of a pandemic, governments around the world took drastic measures, which, while saving lives, have also resulted in dire economic and social consequences. The depth and length of the current economic downturn is likely to be the key factor shaping the future of tourism and EDDs (Hall et al., 2020). Leadership and direction is hard to come by as the three faces of entertainment - the power brokers, the performers and the audience (Pearce, 2008, p. 127) - have all been dramatically affected and appear limited in their ability to tackle the situation even in a concerted way. Likewise, EDDs' tourism stakeholders can only wait on others to lift these restrictions on movement and consumption.

What we do know, however, is that EDDs should continue to implement recovery measures while also preparing for similar reoccurrences and for a range of potential future outcomes. In one way or another, these destinations are going to have to deal with people, infrastructure and communication issues, all of which are bound to converge with concerns from locals over unbridled tourism, sustainability and societal issues, as well as intense competition from potentially every other destination out there. We also note that none of the respondents alluded to counseling or economic diversification as part of their recovery strategies. While the latter can potentially be avoided until the subsequent post-crisis stage, the former can hardly wait and should not be overlooked.

Finally, while certain EDDs appeared better prepared to deal with a given outcome based on their characteristics and development strategy to date, it remains that no destination will come out of the pandemic unchanged. Whatever the "new normal" looks like, EDDs will inevitably have to borrow strategies from each of the four alternate futures. As such, this pandemic should act as a reminder, albeit painful, of the importance for destinations to plan even for seemingly extreme contingencies and to grow resilient in case no one can come to the rescue or at least not soon or for long enough.

\section{References}

Avraham (2015), "Destination image repair during crisis: attracting tourism during the Arab spring uprisings", Tourism Management, Vol. 47, pp. 224-232, doi: 10.1016/j.tourman.2014.10.003.

Avraham, E. and Ketter, E. (2017), "Destination marketing during and following crises: combating negative images in Asia", Journal of Travel \& Tourism Marketing, Vol. 34 No. 6, pp. 709-718, doi: 10.1080/ 10548408.2016.1237926. 
Backer, E. and Ritchie, B.W. (2017), "VFR travel: a viable market for tourism crisis and disaster recovery?", International Journal of Tourism Research, Vol. 19 No. 4, pp. 400-411.

Bremmer, I. (2020), "The next global depression is coming and optimism won't slow it down", Time, August 6th, available at: https://time.com/5876606/economic-depression-coronavirus/

Butler, R. (2009), "Tourism in the future: cycles, waves or wheels?", Futures, Vol. 41 No. 6, pp. 346-352, doi: 10.1016/j.futures.2008.11.002.

Caillou, A. (2020), "Le télétravail en direct d'une chambre d'hôtel", Le Devoir, November 2nd, available at: www.ledevoir.com/societe/588898/le-teletravail-en-direct-d-une-chambre-d-hotel

Campiranon, K. and Scott, N. (2014), "Critical success factors for crisis recovery management: a case study of Phuket hotels", Journal of Travel \& Tourism Marketing, Vol. 31 No. 3, pp. 313-326, doi: 10.1080/ 10548408.2013.877414.

Canada Council for the Arts (2020), "National survey on federal emergency aid measures and the arts sector in Canada", Preliminary Report on the Quantitative Survey Responses, available at: https:// canadacouncil.ca/-/media/Files/CCA/Research/2020/04/Survey-on-Federal-Aid-Measures-and-theArts-Sector-Quantitative-Results-April-14.pdf

Chan, V.K. (2011), "The impact of the global financial crisis on the entertainment tourism industry: a financial engineering case study of Macao from 2007 to 2010", Systems Engineering Procedia, Vol. 1, pp. 323-329.

Dator, J. (1998), "Introduction: the future lies behind! Thirty years of teaching futures studies", American Behavioral Scientist, Vol. 42 No. 3, pp. 298-319, doi: 10.1177/0002764298042003002.

Dator, J. (2019), "Alternative futures at the Manoa school", in Dator, J. (Ed.), A Noticer in Time, Springer, pp. 37-54.

Faulkner, B. (2001), "Towards a framework for tourism disaster management", Tourism Management, Vol. 22 No. 2, pp. 135-147, doi: 10.1016/S0261-5177(00)00048-0.

Faulkner, B. and Vikulov, S. (2001), "Katherine, washed out one day, back on track the next: a postmortem of a tourism disaster", Tourism Management, Vol. 22 No. 4, pp. 331-344, doi: 10.1016/S02615177(00)00069-8.

Filimonau, V. and De Coteau, D. (2020), "Tourism resilience in the context of integrated destination and disaster management (DM2)", International Journal of Tourism Research, Vol. 22 No. 2, pp. 202-222, doi: 10.1002/jtr.2329.

GLS Research (2018), "Las Vegas visitor profile study", available at: https://assets.simpleviewcms.com/ simpleview/image/upload/v1/clients/lasvegas/2018_Las_Vegas_Visitors_Profile_Study_94443c1d334f-4d0b-b997-5c8800f990b0.pdf

Gössling, S., Scott, D. and Hall, C.M. (2020), "Pandemics, tourism and global change: a rapid assessment of COVID-19", Journal of Sustainable Tourism, Vol. 29 No. 1, pp. 1-20, doi: 10.1080/ 09669582.2020.1758708.

Gotham, K.F. (2017), "Touristic disaster: spectacle and recovery in post-Katrina New Orleans", Geoforum, Vol. 86, pp. 127-135, doi: 10.1016/j.geoforum.2017.09.005.

Hall, C.M., Scott, D. and Gössling, S. (2020), "Pandemics, transformations and tourism: be careful what you wish for", Tourism Geographies, Vol. 22 No. 3, pp. 1-22, doi: 10.1080/14616688.2020.1759131.

Hissong, S. (2020), "How coronavirus is destroying the livelihood of music's behind-the-scenes workforce", Rolling Stone, 16 March, available at: www.rollingstone.com/pro/features/coronaviruscanceled-tours-behind-the-scenes-967499/

Hughes, H. (2013), Arts, Entertainment and Tourism, Oxford, Butterworth-Heinemann.

Imbert, F. (2020), "Dow falls 900 points as wall street fears coronavirus will shut down economy longer than expected", CNBC, 31 March, available at: www.cnbc.com/2020/03/31/stock-market-futures-opento-close-news.html

Jayawardena, C., Tew, P.J., Lu, Z., Tolomiczenko, G. and Gellatly, J. (2008), "SARS: lessons in strategic planning for hoteliers and destination marketers", International Journal of Contemporary Hospitality Management, Vol. 20 No. 3, pp. 332-346, doi: 10.1108/09596110810866145.

Kirkpatrick, M. and Lee, J. (2020), "After pandemic, a blueprint for reopening our economy”, Las Vegas Sun, 12 April, available at: https://lasvegassun.com/news/2020/apr/12/after-pandemic-a-blueprint-forreopening-our-econo/ 
Komenda, E. (2020), "Coronavirus and casinos: how long can Las Vegas companies survive a shutdown? Statesman, 27 march", available at: www.statesman.com/zz/lifestyle/20200327/coronavirusand-casinos-how-long-can-las-vegas-companies-survive-shutdown

Krueger, R.A. and Casey, M.A. (2000), Focus Groups: A Practical Guide for Applied Research, 4th ed., Thousand Oaks, CA, Sage.

Kuznia, R. (2020), "Las Vegas entertainers fear dire straits as weeks of unemployment turn to months", CNN, 13 August, available at: www.cnn.com/2020/08/13/us/las-vegas-tourism-coronavirus-impact-invs/index.html

Labbé, J. (2020), "L'Hôtel place dupuis comme solution de rechange au campement Notre-Dame", La Presse, 29 October, available at: https://ici.radio-canada.ca/nouvelle/1745471/plan-itinerance-hivercamping-hochelaga-montreal-pandemie-covid-19

Lim, J. and Won, D. (2020), "How las Vegas' tourism could survive an economic crisis?", Cities, Vol. 100, doi: 10.1016/j.cities.2020.102643.

Loi, K.I. and Pearce, P.L. (2012), "Powerful stakeholders' views of entertainment in Macao's future", Journal of Business Research, Vol. 65 No. 1, pp. 4-12, doi: 10.1016/j.jbusres.2011.07.008.

Luo, J.M. and Lam, C.F. (2017), Entertainment Tourism, New York, NY, Routledge.

Morgan, D.L. (1988), Focus Group as Qualitative Research, Newbury Park, CA, Sage.

Nyumba, T.O., Wilson, K., Derrick, C.J. and Mukherjee, N. (2018), "The use of focus group discussion methodology: insights from two decades of application in conservation", Methods in Ecology and Evolution, Vol. 9 No. 1, pp. 20-32, doi: 10.1111/2041-210X.12860.

Page, S.J., Yeoman, I., Connell, J. and Greenwood, C. (2010), "Scenario planning as a tool to understand uncertainty in tourism: the example of transport and tourism in Scotland in 2025", Current Issues in Tourism, Vol. 13 No. 2, pp. 99-137, doi: 10.1080/13683500802613519.

Page, S., Yeoman, I., Munro, C., Connell, J. and Walker, L. (2006), "A case study of best practice-visit Scotland's prepared response to an influenza pandemic", Tourism Management, Vol. 27 No. 3, pp. 361-393, doi: 10.1016/j.tourman.2006.01.001.

Parsons, W. (1996), "Crisis management”, Career Development International, Vol. 1 No. 5, pp. $26-28$.

Pearce, P.L. (2008), "Tourism and entertainment: boundaries and connections", Tourism Recreation Research, Vol. 33 No. 2, pp. 125-130, available at: https://doi-org.ezproxy.lib.ryerson.ca/10.1080/ 02508281.2008 .11081299

Postma, A. (2015), "Investigating scenario planning: a European tourism perspective", Journal of Tourism Futures, Vol. 1 No. 1, pp. 46-52, doi: 10.1108/JTF-12-2014-0020.

Ricciardelli, M. (2020), Nearly 3 of 4 Americans Won't Attend Games without Coronavirus Vaccine Developed, Seton Hall University, available at: http://blogs.shu.edu/sportspoll/2020/04/09/nearly-3-of-4americans-say-they-wont-attend-games-without-coronavirus-vaccine-developed/

Ritchie, B.W. (2004), "Chaos, crises and disasters: a strategic approach to crisis management in the tourism industry”, Tourism Management, Vol. 25 No. 6, pp. 669-683, doi: 10.1016/j.tourman.2003.09.004.

Roberts, V. (1994), "Flood management: Bradford paper", Disaster Prevention and Management: An International Journal, Vol. 3 No. 2, pp. 44-60, doi: 10.1108/09653569410053932.

Sayre, K. (2020), "In Las Vegas, coronavirus job losses could double those of 2007-09 recession", The Wall Street Journal, 9 April, available at: www.wsj.com/articles/in-las-vegas-coronavirus-job-lossescould-double-those-of-2007-09-recession-11586433601

UNWTO (2020), "International tourist arrivals could fall by 20-30\% in 2020", available at: www.unwto.org/ news/international-tourism-arrivals-could-fall-in-2020 (accessed 8 June 2020).

Whitten, S. (2020), "New York city misses out on billions of tourism dollars as coronavirus keeps Broadway dark", CNBC, 29 September, available at: www.cnbc.com/2020/09/29/coronavirus-broadwaynyc-shuttered-until-2021.html

World Health Organization (2020), "Coronavirus disease 2019 situation report 51", 11 March, available at: www.who.int/docs/default-source/coronaviruse/situation-reports/20200311-sitrep-51-covid-19.pdf? sfvrsn=1ba62e57_10

World Tourism Organization (2020), "International tourist numbers down 65\% in first half of 2020", 15 September, available at: www.unwto.org/news/international-tourist-numbers-down-65-in-first-half-of2020-unwto-reports 
Yeoman, I. (2012), "2050: Tomorrow’s tourism”, Aspects of Tourism, 55. Bristol, Channel View.

Yeoman, I. and McMahon-Beattie, U. (2005), "Developing a scenario planning process using a blank piece of paper", Tourism and Hospitality Research, Vol. 5 No. 3, pp. 273-285, doi: 10.1057/palgrave.thr.6040026.

Zenker, S., von Wallpach, S., Braun, E. and Vallaster, C. (2019), "How the refugee crisis impacts the decision structure of tourists: a cross-country scenario study", Tourism Management, Vol. 71, pp. 197-212, doi: 10.1016/j.tourman.2018.10.015.

Zoltner, A., Sinha, P.K. and Lorimer, S. (2020), "4 things sales organizations must do to adapt to the crisis", Harvard Business Review, 13 April, available at: https://hbr.org/2020/04/4-things-salesorganizations-must-do-to-adapt-to-the-crisis

\section{Further reading}

Kwon, Y., Lim, J. and Kim, E. (2020), "Diversifying visitor demand and its impact on Las Vegas's tourism industry during recovery from the great recession", Regional Science Policy \& Practice, Vol. 12 No. 2, pp. 249-266, doi: 10.1111/rsp3.12216.

Martin, I. (2020), "Cirque du Soleil lays off 95\% of staff over coronavirus pandemic shutdown", Forbes, 20 March, available at: www.forbes.com/sites/iainmartin/2020/03/20/cirque-du-soleil-lays-off-95-of-staffover-coronavirus-pandemic-shutdown/?

Rendon, F. (2020), "Petition leads to formation of live events coalition to lobby for production, event professionals", Pollstar, 20 March, available at: www.pollstar.com/article/petition-leads-to-formation-oflive-events-coalition-to-lobby-for-production-event-professionals-144003

\section{About the authors}

Louis-Etienne Dubois is an Associate Professor at Ryerson University's School of Creative Industries and an Associate Researcher at MINES ParisTech's Center de Gestion Scientifique and director of the Future of Live Entertainment lab. He holds a PhD from HEC Montréal and from MINES ParisTech. Louis-Etienne Dubois is the corresponding author and can be contacted at: le.dubois@ryerson.ca

Frederic Dimanche is the Director of Ted Rogers School of Hospitality and Tourism Management. He obtained his PhD from the University of Oregon and then worked as a Professor in the School of Hotel Restaurant and Tourism Administration at the University of New Orleans.

For instructions on how to order reprints of this article, please visit our website: www.emeraldgrouppublishing.com/licensing/reprints.htm

Or contact us for further details: permissions@emeraldinsight.com 